\title{
Ssciendo
}

Ethics \& Bioethics (in Central Europe), 2019, 9 (3-4), 168-180

DOI:10.2478/ebce-2019-0019

\section{Bioethical motifs in the literary work of Karel Čapek}

\author{
Petr Jemelka ${ }^{1}$
}

\begin{abstract}
This text presents an assessment of the literary work of Karel Čapek from a perspective that has not yet been discussed. It focuses on analysing Čapek's works from the viewpoint of their possible inspiration by bioethical issues. Čapek's philosophy and the powerful ethical charge of his texts tend to be associated with his interest in pragmatism, a subject to which he, however, took an individual and critical approach. One of the most important categories of his way of thinking is life. In his prose works and plays we therefore see motifs that may be associated with the thematic definition of bioethics. These are questions concerning the value and quality of human life, issues concerning the dehumanizing impact of science and technology, as well as reflections upon the moral dimension of man's relationship to nature and also to the relationship between people and animals. Čapek's work may therefore provide inspiration from the perspective of the history of the gradual formation of the bioethical point of view.
\end{abstract}

Keywords: bioethics, literature, life, humanity, science

\section{Introduction}

The literary work of Karel Čapek (or both Čapek brothers) is undoubtedly of lasting value, in many ways extending beyond the framework of our national spiritual culture. Another highly apt characteristic is the title of the film version of the end of Čapek's life - Člověk proti zkáze [Man versus Ruin]. ${ }^{2}$ By this we mean that Čapek's setting in the period situation of interwar Czechoslovakia and Europe and his awareness of the gradually intensifying crisis and the threat of a breakdown in values, enabled the creation of literary works that embody a timeless humanism. Their artistic value is a lasting cultural mainstay supported by a remarkable philosophical base and moral appeal.

These aspects have of course already been the focus of interest and research. Even so, in this article we want to justify the view that even today there are sides of Čapek's literary legacy that have not yet been the focus of adequate attention. Specifically, this study will attempt to answer the question of whether we are right in also considering Čapek's texts as an interesting incentive to reflect upon the development of bioethically motivated thinking. It seems that this point is still hampered by a certain simplifying schematic interpretation, one that merely evaluates potential "biologizing" motifs as allegories (particularly the impending rise of totalitarian regimes at the time) without exploring the matter any more deeply. We are therefore faced with the question of whether we can reveal Čapek's more specific interest in working with themes that entail scientific and technological development in the category of life in its deepest meaning. Incidentally, Čapek came from a doctor's family. However, let us also bear in mind that "... the philosophical interpretations of fiction should always take account of Mukařovsky's words that the search for the philosophy of a certain work of art is actually the conversion of a work of art into conceptual language, which entails the risk of a subjective interpretation" (Zouhar, 2008, p. 194).

\section{Philosophy, ethics and fiction}

We could base our considerations on an evaluation of the potential offered to philosophy (and ethics) from an area of non-theoretical work - fiction. Here we realise that philosophy should

\footnotetext{
${ }^{1}$ Masaryk University, Faculty of Education, Brno (Czech Republic); 1178@mail.muni.cz

2 1989, directed by Štěpán Skalský.
} 
not limit itself to a certain interpretation of the world, but that its true purpose is to strive to understand the relationship between the world and man. Therefore, it should not only say "this is how it is," but should also be able to explain how it came to this conclusion and also show what that means for us. How we should deal with the world and ourselves, what to do and why, and, on the other hand, what to avoid - which is now axiology and ethics: "... philosophy has resolved and continues to resolve a more or less constant set of questions that keep returning the problem of existence, space and time, movement and development, truth and truthfulness, values and evaluation. On the other hand, philosophy is bound to a certain era, expresses its questions and responds to them in a manner conditioned by the time ... it reflects and also helps to shape the spiritual atmosphere of the age" (Zouhar, 2008, p. 192).

It is here that we find points of contact between science, philosophy and the artistic message of literature. Incidentally, we know from history that many philosophers opted to express their ideas in an artistic form (Nietzsche, Sartre, etc.). If we consider the Czech author at this point, we can also fully concur with the following statement: "For Czech thinking it is then even more true that particular thought tendencies are not necessarily expressed in philosophy, but, in certain contexts, may be updated in art ... And thus it is incontestable that certain leading figures in the history of Czech literature and art have at the same time played a major role in shaping the thought atmosphere of Czech society. Their works of art, and also their essays and theoretical works, deal with serious philosophical questions aimed at understanding and grasping the subjectivity in modern society, at reflecting upon period social and political problems, at discussing the philosophy of Czech history and seeking a relationship with religion" (Zouhar, 2008, p. 191).

Basically, it may be said that the literary form is one important way of preserving that human dimension of the philosophical message. That is what it is all about; we can concur with the now unjustly forgotten philosopher V. Gardavský, whose philosophical, religionist and artistic texts $^{3}$ reflect the spiritual atmosphere of another key era in our history - the atmosphere of the nineteen sixties.

\section{Brief note on the philosophy of Karel Čapek}

Karel Čapek is not considered merely as an artist and publicist; frequent reference is also made to his long-standing interest in philosophy (which, incidentally, he had a university degree in). In this context it is also usual to draw attention to Čapek's tendency towards pragmatism. This is derived from Čapek's professional study on this topic, which was later reflected in his literary work (the one that particularly tends to be mentioned is the "Noetic" trilogy - Hordubal, Povětroň [Meteor] and Obyčejný život [Ordinary life]).

On the margins of this interpretative tradition, however, a more specific note should be made. That study on pragmatism was originally just Čapek's student seminar work in 1914. It came out as a book entitled Pragmatismus čili Filosofie praktického života [Pragmatism, or The philosophy of the practical life] in 1918, followed by an extended edition in 1925 (Čapek, 1918). Capek completed his studies in 1915, with his doctoral dissertation focused on the methodology of visual art aesthetics. (Zouhar, 1998, pp. 79-81) Čapek's study of philosophy was definitely strongly influenced by the positivist atmosphere that was prevalent in this country at the time (incidentally, he presented his work on pragmatism at František Krejčí's seminar). However, during his time spent studying in Berlin and Paris, he also came across other stimuli (Bergson's vitalism, the civilizational scepticism of O. y Gasset). Pragmatism itself (as pointed out by Karel Vorovka in his Americká filosofie [American Philosophy] (Vorovka, 1929) was, for Europe, a surprising manifestation of new philosophical possibilities. All of this combined to shape Čapek's path to his highly specific critical adoption of

\footnotetext{
${ }^{3}$ E.g. Naděje ze skepse [Hope from Skepticism], Bůh neni zcela mrtev [God Is Not Yet Dead], Já, Jákob [I Jacob], Andèl na hrotu meče [Angel on the Tip of a Sword], etc.
} 
pragmatism. After all, Čapek did not become a mere epigon. He did not stop at pragmatic noetics, but constantly called for compliance with the criterion of rationality in the field of knowledge. What he mainly drew from pragmatism were its moral dimension and the refocusing of attention from abstract topics to everyday life. Incidentally, Čapek's distaste for the subordination of the value of authentic human life to the abstract values of so-called ideology can be seen very early, before he began to take an active interest in pragmatism. Back in 1910 he wrote the following on the unfortunate patriotic idealization of national history and particularly figures in that history: "There exists something like a Czech demon or some sort of curse. Imagine a very strange cruelty here: removing man from our history and stuffing him with ideas, ideology, moralism, virtue and politics; but alas! That man was alive until then, and died only when he was stuffed. But that is not cruelty; is it not perhaps a lack of feel for life, for temperature, for uncooled organisms? It is a kind of Czech demon (and now there may follow a series of translations from yesterday and today). It is strange what is being done with history in this country: it is like a revaccination of national ideas; and as a result of this vaccination some sort of sacrificial, altar animals generally come..." (Čapek, 1910, p. 75).

For Karel Čapek the most valuable thing about pragmatism was that it aspired to be a philosophy in the service of life: "For Čapek, 'his' pragmatism was one way to express his affinity with life and people, an affinity that was certainly benevolent and kind, but also responsible, and thus, if necessary, also critical and implacable" (Gabriel, 2002, p. 33).

And so, in Krakatit for instance, we first find this appreciation of the simple life, when Prokop wants to give up reason: "But here, here I started to be happy. Here I found that perhaps ... there is nothing better than to think. Here one just lives ....and sees that it is something tremendous ... simply to live ... Every animal has the ability ... and it seems to me so tremendous, as if I had never lived before now" (Čapek, 1989, p. 69). However, at the close of this novel he is corrected by Grandfather, ${ }^{4}$ warning of the importance of reason for life, for human action:

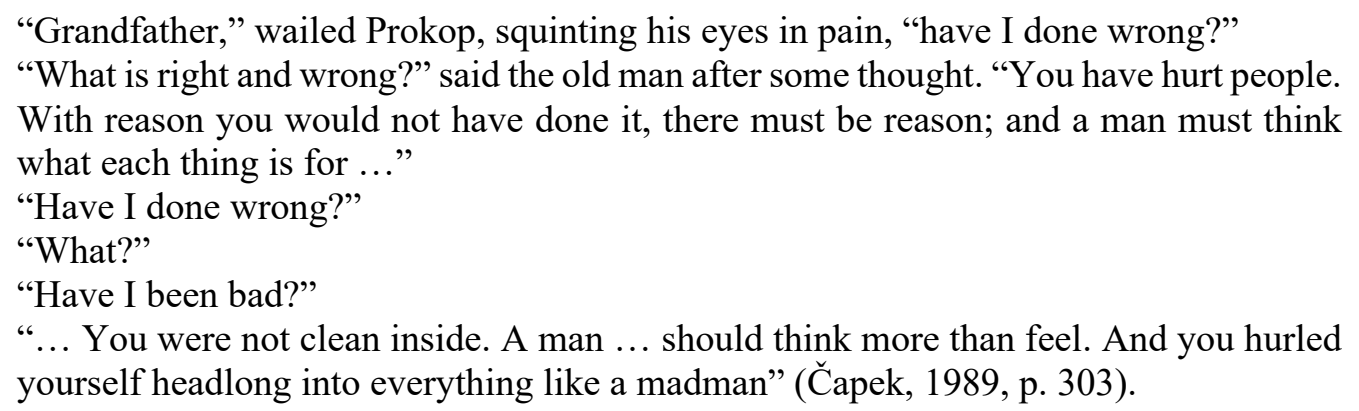

And from that life-targeting aspect of pragmatism, emphasised even further by Čapek, we can derive a certain argument to support our exploration of the bioethical dimension of Čapek's work. Incidentally, at roughly the same time the topic of the value of (not only human) life becomes the focus of attention for other authors. For instance, Albert Schweitzer's ethics of respect for life appeared, while in the thoughts of the German pastor F. Jahr we find the term bioethics; Aldo Leopold comes up with a new categorical imperative in his Land Ethic. Not even vitalism (neovitalism) had said its last word - in fact, (in Lessing's work) it found a new motif criticising civilisation. František Mareš shaped his philosophy of respect from a vitalistic perspective. In fact, we could even consider the praise for the traditional peaceful peasant life in rural form ${ }^{5}$ and similar motifs expressed by Heidegger (and also, however, in the in the terrible mysticism of Blut und Boden [Blood and Soil] ideology).

\footnotetext{
${ }^{4}$ This character is a certain personification of God.

${ }^{5}$ See e.g. Čep's Dvojí domov [Double being].
} 
Broader period philosophical contexts point to another remark regarding Čapek's international recognition and foreign reflections on his works. The serious nature of the questions Čapek posed are a source of lasting interest in his work (not only within the Czech Republic). The view presented in this paper will take neither historiographical (or biographical) works by foreign authors nor their papers in literary science into consideration. ${ }^{6}$ What it wants to offer is a concise insight into the efforts of foreign theoreticians to grasp the philosophical dimension of Čapek's work. One might like to note that it is Čapek's play R.U.R that is of special interest. This is likely caused by people's awareness of the word 'robot' and the general attractiveness of how Čapek treated the topic. William E. Harkins' 1960 paper tracing the parallels between Čapek's and Tolstoy's play could be included in this incomplete selection. The origination and originality of Tolstoy's play could be considered rather problematic: "Thus Tolstoy suggested that the idea of R.U.R. was in effect common property, an international literary theme" (Harkins, 1960, p. 312). According to the same author (Harkins, 1960, p. 314), the comparison of both works can, therefore, result in interesting findings regarding the worldviews, or the philosophical view, of both authors. While Tolstoy represents Marxism, in Čapek's case it is vitalism (Harkins, 1960, p. 316).

A paper comparing Čapek's work with Vita Activa [The Human condition] by H. Arendt provides another interesting view on R.U.R. Matthew Dinan studies, in both the above texts, the motifs of human labour, technological progress and their impact on human life (including alienation). What Čapek and Arendt share is their critical view of German idealism (Dinan, 2017, pp. 108, 116).

This brings us to another paper inspired by Čapek's R.U.R (Kinyon, 2014). This text directly focuses on the philosophical aspects of the play, including pointing to the problem with the translation: "Unfortunately, many of the philosophical implications of Čapek's play have become lost in English translation" (Kinyon, 2014, p. 243). The author has found out that the text bears deeper traces of Čapek's philosophical education: "Čapek was a philosopher before becoming a writer of fiction, and as I will argue, his play contains an implicit criticism of Hegel's master-slave dialectic and of Kant's categorical imperative" (Kinyon, 2014, p. 240).

Apart from the above partial monothematic analyses, let us now mention those works by an author who had dealt with the philosophical dimension of Čapek's work in a long-term and systematic way - William E. Harkins. The life of this author is, in a remarkably broad range, linked with the field of Slavic studies (starting with folklore and finishing with translation). He was one of the first American theoreticians to deal with modern Czech literature. At this point, one could mention his inspirational conference paper (Harkins, 1958), providing a critical view of Karel Čapek being traditionally and unambiguously classified under the umbrella of pragmatism. The author claims that this link can only be applied to his early work ${ }^{7}$ (which is true of both Čapek brothers). In their stories (later issued in the 1916 collection Zárivé hlubiny [The Luminous Depths]), the Čapek brothers expressed a positive and joyful view of life, which they themselves labelled as pragmatic. However, William E. Harkins adds: "In these stories the Čapeks show a certain ethical simplification of Bergsonian vitalism or pragmatism as systematic philosophies. But the influence of Karel's philosophical studies on these tales can hardly be doubted. In the final story of the collection, 'Zárivé hlubiny' (The Luminous depths), the positive vision is suddenly lost. To human progress is opposed the concept of chance, and the two are found to be irreconcilable... The next collections ... are deeply pessimistic" (Harkins 1958, p. 11). Consequently, the author points to the, somewhat complex, situation around

\footnotetext{
${ }^{6}$ That is why the paper on Čapek's relationship to, the otherwise philosophically interesting, Chesterton is only mentioned very briefly (Bradbrook, 1961). The author only focuses on the level of literary analysis; numerous parallels can be found when the works by both authors are compared, which even made her call Gilbert K. Chesterton Čapek's teacher (Bradbrook, 1961, p. 337).

${ }^{7}$ The author revisited this topic in his much later paper (Harkins, 1992).
} 
Čapek's alleged permanent relativism: “Though for a time Čapek sought to make relativism a positive element in his philosophy, he failed in this: in the end his pluralist vision of life took over the positive role in his thought, and relativism was abandoned completely. In his trilogy of three novels (Hordubal, Povětroň, Obyčejný život [Hordubal, Meteor, Ordinary life], 19331934), he gave up relativism for a new, more completely absolutist faith in mankind as a uniform and stable essence: all men are akin since they share this essence" (Harkins, 1958, p. 18). This paper also reflects on other Czech authors (Miroslav Rutte and František Langer) and is, thus, an interesting contribution in broader discourse regarding the situation in Czech interwar literature.

William E. Harkins is also the author of a completely unique monograph, presenting a summary of his systematic interest in Čapek's work (Harrkins, 1962). Although not too voluminous, the work, unlike the partial efforts reflected upon above, provides a systematic analytical view of a great deal of Čapek's literary work. Moreover, when studying the philosophical nature of Čapek's work, the changes and the development of his life philosophy form a significant part of this complex view on Čapek's person and work by a foreign scholar, that has not been outdone until the present day. In Harkins' words: "Čapek was a philosophical writer par excellence. Perhaps no one of his generation tried so systematically and consciously to express philosophical ideas through literature" (Harkins, 1962, p. 168). This work by Harkins as such then comes to the general conclusion that, when interpreting the philosophical aspects of Čapek's work, a simple schematism is definitely not enough: "[A] paradox of philosophical ideas is an important trait in Čapek's writing.... Čapek's favorite philosophical theme was, of course, relativism. But great literature must impart a sense of wonder and mystery to life, not deprive life of richness of meaning" (Harkins, 1962, p. 170). That is why the whole of Capek's work is varied and offers, in individual texts, in different creative stages, diverse approaches and perspectives. Thus, Harkins' work is, until the present day, a significant inspirational source for contemplations on the role and importance of Karel Čapek in the Czech, as well as world, spiritual culture and, at the same time, the philosophy of Čapek's work.

\section{Modern science and technological development}

In Harkins' work, one could also find a mention of Čapek being one of the few authors of his period who included modern science and technology in their work (Harkins, 1962, p. 168). It is true Čapek paid close attention to the conquests of interwar national and foreign science and was sensitive to the key topics and issues many theoretical and technological fields dealt with. It was biology-related fields of study that expanded remarkably in this period of time. In addition to this, Čapek also evidently followed developments in interwar science, both Czech and foreign. Biological disciplines were a remarkably expanding component in science during this time. Efforts to penetrate through to the essence of life (physiology, genetics) also led to the emergence of so-called marginal scientific disciplines (biophysics, biochemistry) - and we may then see R.U.R., for example, as one outcome of this interest of Čapek's, as "biochemical theatre". In the inanimate nature sciences, the inspiration for this lay in the completely new results of quantum and relativistic physics; Krakatit is entirely based on the notion of the amazing and terrifying potential of nuclear fission. In this, Čapek even soon (Krakatit is from 1924, Továrna na Absolutno [The Absolute at Large] is two years later) showed a greater degree of clairvoyance than our positivists, who generally rejected modern tendencies in physical theory as mere speculation.

However, Čapek did not view the development of science and subsequent new technological possibilities with naive optimism. ${ }^{8}$ His works warn against unleashing the dehumanized destructive forces of technology and science, and the terrors of this new power. This, for

\footnotetext{
${ }^{8}$ In the period between the wars, for instance, Husserl brought to philosophy a sceptical view of the problems of science and its influence on man and his world.
} 
example, is the (Nietzschean) argument put forward by Daimon Prokop in Krakatit: "Do not count lives; work on a large scale, and the whole world has billions of lives... You are the first man in the world who may consider the whole world his laboratory... a creator who is not a supreme lord and ruler, but is merely a fool" (Čapek, 1989, pp. 267-268)

Through his work Čapek was thus anchored firmly in the growing problems of his age. However, in those problems he found not only partial questions that varied over time, but above all painfully perceived a threat that would affect the very value of humanity and life. This is another reason why we make so bold to find themes in his works that rightfully belong to bioethics.

\section{Utopia and ethics}

Despite recognising the importance of Čapek's literary legacy, certain doubts may still arise whether it is truly appropriate to seek such serious motifs in a literary genre that is considered by many to be marginal literature, if not pulp fiction. ${ }^{9}$ Such a view could raise the question of whether the moral importance of many of Capek's utopian works may truly be compared with the moral charge of the novels of Balzac, Dickens or Kundera.

A positive answer may be given to this question in at least two ways. Firstly, we may argue generally in favour of the sci-fi genre in the sense that it cannot be reduced to mere shallow entertainment. After all, this genre also reflects serious themes that are so new and surprising that "more serious literature" has not yet managed to take over, as, for example, they are linked to specific and highly specialised information on developments in research and technology. Incidentally, back in 1962 the value and importance of sci-fi literature for ethics was acknowledged by Jiřina Popelová, even though she did take a somewhat biased and ideologically-based view in comparing the literary works of Western authors and authors from the Eastern Bloc. According to her, some form a pessimistic anti-Utopia, while others offer optimistic and inspiring ideas of a bright future (Popelová, 1962, pp. 225-227).

The second means of defending the deep moral importance of Capek's work could start with the following question - what does the Utopian nature of Čapek's works actually involve? And here we find that in each case these are texts with a powerful and exciting story, sometimes action-packed, sometimes set in exotic locations. So far, marginal literature. Válka s mloky [War with the newts] may thus be reminiscent of the adventures of Biggles. One remarkable match in the case of Válka s mloky [War with the Newts] is that the same year (1936) saw the publication of H. P. Lovecraft's famous horror novella The Shadow over Innsmouth, which is also about an invasion of aquatic monsters. However, there is one significant difference. Lovecraft's text is nothing more than an undoubtedly good, suggestively written and wellstructured horror. In contrast, Čapek's tale takes the form of an adventure story to reflect on the real rise of a totalitarian regime, and is thus a kind of easily understandable allegory or parable.

In the more general sense, we can say that the Utopian nature of Čapek's works stems from his use of a common imagination that extends beyond inspiration drawn from science and technology. However, Čapek did not abandon his imagination for vague and expansive excursions, but is always well grounded in the real form and direction of research and technical development. He thus elaborates on questions already raised by science. Yet he does not stop there; his works are not engaging for their futuristic view in the style of Jules Verne. Čapek's (not only) Utopian work presents significant, primarily moral, questions - human values, the possibilities and limitations of freedom and decision-making and always the eternal cost of life. "In all works a Utopian (fantasy) object - subject becomes a principle that unveils reality, revealing its contradictions, differentiating human characters, unmasking all spheres of human activity" (Hodrová, 1987, p. 86). Those fantasy motifs and backdrops are thus primarily means

\footnotetext{
${ }^{9}$ The Czech literary Karel Čapek Prize for sci-fi works is a statue of a black newt.
} 
of obtaining readable forms and particularly surprising perspectives, which explore moral issues that are both traditional and may be expected to arise in the future. A gripping and readable powerful story with a humanistic message - that is what cannot simply be dismissed by a contemptuous reference to mere Utopianism: "In the works of Karel Čapek Utopia gradually ceased to be ... something separated from fact by a Utopian distance as in the classic Utopia, and became ever more markedly the thing through which fact passes, which is a hidden reality" (Hodrová, 1987, p. 103).

\section{The three pillars of bioethics in Čapek's texts}

Let's now attempt to take a more specific and summary look at the individual aspects that make up bioethics as a whole (human life and health, environmental ethics and issues of so-called animal ethics) in Čapek's work. His anti-Utopia ${ }^{10}$ and other formats of his literary work reflect all these three areas of bioethics in a certain manner. We are not interested in providing an exhaustive list of all such texts and seeking out all the slightest allusions they contain. Instead, we will try to offer a selection of texts in which bioethical motifs feature most distinctly.

Even so, let us start our selection with texts whose true meaning, although evidently inspired by biology, lies in another of the author's motivations. So, we may say that the play Ze života hmyzu [The Insect play], as well as his later novel Válka s mloky [War with the newts] use animals in a surrogate sense. The aforementioned play is a genre fable (or band of fables) that highlights morally problematic forms of human behaviour. Although Válka s mloky [War with the newts] works with the idea of the environment having been extensively devastated by an invasion of an aggressive species of animal, its message is allegorical. It is a warning against the threat of the expansion of a specific totalitarian regime, which soon proved to be particularly topical and tragic. It is thus a warning against defeatist inaction or, on the other hand, against the active support of evil. "Čapek clearly sees this 'other' being as the result of human activity, as something that has unleashed itself from man or which, through man's actions, has developed into an independent existence, on that it dangerous to man" (Hodrová, 1987, p. 91). The novel also has a very valuable dimension - humour. ${ }^{11}$ By this means Čapek (like Jaroslav Hašek before him) faces the brutal threat of violence and war: "Chief Salamander is a man. His name is Andreas Schultze and during the world war he was a Master-Sergeant somewhere" (Čapek, 1953, p. 268). And another more general ironic barb: "Have you ever come across anything so terrible and murderous that an intellectual wants to use it to revive the world?" (Čapek, 1953, p. 266).

Motivated in a similar manner was Čapek's older Krakatit, which mostly warns against the abuse of science for the purposes of war. Here we can draw analogies with Utopias presented along similar lines by Troska. However, those are considerably naive in their means, optimistic in their consequences and problematic in their overall tone. Nemo's realm watches out for world peace, which it can also bring about by force. However, this is simply another form of societywide totalitarian control. Troska's ambitions as an author never went beyond the bounds of adventure literature for youngsters.

However, the situation is entirely different in the case of Čapek's Bilá nemoc [The White plague]. Once again, the main motif there is the threat of another world war. In the foreword to this play Čapek wrote: "One of the characteristics of post-war humanity is its retreat from what is sometimes, almost with contempt, called humanity" (Čapek, 1956, p. 265). Čapek associates this departure from the traditional value of human life and human rights with the rise of

\footnotetext{
10 Čapek was sceptical in his portrayal of ideas concerning the possible conquests of human science and technology. In the context of the growing crisis in interwar society his view explores the problematic consequences and impending risks and so here it is entirely appropriate to refer to the genre as being anti-Utopian.

${ }^{11}$ Rather surprisingly, Čapek also described some of his plays as comedies: "I stand up for everyone; perhaps that is why I write comedies instead of dramas. That is the insatiable emotion in my life..." (Čapek, 1968, p. 298)
} 
totalitarian ideologies. In the name of class, the state, the nation or race, these ideologies strive to establish an autocratic regime, in which man is wholly and violently subordinate to those socalled higher units: "... this is a conflict between the ideals of democracy and the ideals of unrestricted and ambitious dictatorships" (Čapek, 1956, p. 266).

In this play the reversal in values is symbolised by a pandemic of an incurable disease, the symptoms of which resemble leprosy. With this theme Čapek again stressed the threat of a crisis to humanity, as "... a sick and wretched person is compulsively and typically a subject of humanity" (Čapek, 1956, p. 266). Here, drawing on a bioethical problem (medical ethics), Čapek escalated an entire conflict between a fierce "craving for power" and the humanitarian ideal. Doctor Galén has discovered an effective drug to treat the white plague. As an idealist, he wants to use his discovery to force the preservation of peace. In the name of humanity and as a token of respect for human life he therefore "... refuses to help the suffering, as he himself fatally accepts the inexorable morality of the struggle" (Čapek, 1956, p. 267). He is consciously compromising the original mission of a doctor - in his hope of saving world peace. However, he meets with a tragic end (he is trampled by a crowd), thus bringing an end to hope. Capek adds: "However the war ends, a war whose tumult is brought to a close by the white plague, what is certain is that in his suffering Man has remained unsaved" (Čapek, 1956, p. 267). Čapek points out that this tragic conclusion is no solution. He did not want to offer any false hope of a miracle in a situation of real escalating threat. Ending like this, the play is supposed to be a call to fight a real battle, one which affects everyone not as members of the theatre audience, but as those who really will have to go through that battle, "... those who must know on which side of the global dramatic conflict lies the whole right and the whole life of a small nation" (Čapek, 1956, p. 268).

Human life and its value and quality also form part of another of Čapek's well-known plays - Věc Makropulos [The Makropulos affair]. ${ }^{12}$ However, it was written a long time before Bílá nemoc [The White plague] (in 1922), specifically inspired by science, and Capek described it as a comedy. One again, the central motif is a bioethical matter - the possibility of prolonging human life. After drinking a certain alchemical potion, the main character lives for more than three hundred years, during which time she has to change her identity. She is worn out and sick of living so long and eventually decides to forego the elixir. Eventually, the final conflict shows that a long life in itself is not necessarily attractive or happy, and so the formula for the potion is destroyed.

Čapek offered a remarkable reason to justify such an ending (which is otherwise typical for a great deal of fantasy prose). The author compares his allegedly pessimistic stance with the opinions of G. B. Shaw, who saw the potential for prolonging human life as offering a very valuable objective, i.e. the establishment of a kind of future paradise. In his play, however, Čapek “... depicts longevity in a very different light, as something far from ideal and even very undesirable. It is hard to say what is right; unfortunately, there is a lack of experience on both sides" (Čapek, 1956, p. 185). He therefore defends himself against accusations of pessimism: "I don't know if it is optimistic to claim that living for sixty years is bad, yet living for three hundred years is good; I just think that declaring an (average) sixty-year life as reasonable and pretty good is hardly criminal pessimism" (Čapek, 1956, p. 186). After all, it is not merely the length of one's life that is important, but the quality of that life: "If we say that one day in the future there will be no illness, poverty or dirty toil, that is pure optimism: yet to say that our life

\footnotetext{
12 This play also served as the basis for a musical work - Leoš Janáček is the composer of an opera of the same name (he also wrote the libretto to it, with Čapek's permission). Given our topic, for the sake of interest we should add that Janáček's work also contains other bioethical motifs - see another of his operas, Jeji pastorkyña [Her Stepdaughter] (the murder of a newborn child), Kát’a Kabanová [Katya Kabanova] (suicide) and Př́hody lišky Bystroušky [The Cunning Little Vixen] (man's relationship towards animals, and also age); of his piano works, see Sýček neodletěl [The Barn Owl Has Not Flown Away] (illness and death).
} 
today, rife as it is with illness, poverty and toil is not so bad or damned and possesses something incredibly valuable, that is - what exactly? Pessimism? I don't think so. Perhaps it is double optimism: one that turns away from bad things to something better, perhaps even a dream; the other, which seeks at least something a little better in every bad thing ... The first is seeking nothing short of paradise: there is no more beautiful aim for the human soul. The second is seeking here and there for at least morsels of relative good" (Čapek, 1956, p. 186). In the spirit of Šrámek "life of misery, yet how I love you" Čapek is expressing his pure love for life - no matter how difficult or painful it can be. One has to live. This is not resignation, Čapek rejects that: "Believe me, there is one true pessimism, and that is the one that folds its arms; I'd say, ethic defeatism." (Čapek, 1956, p. 186). He also rejects this defeatism in his Kalendár [Calendar], in the part entitled Solace: "Whatever we say, we're heading for foul weather; but hey, we are already ready to grow and get stronger ... something might freeze and dry out, but no loss can thwart our grand and carefully prepared programme: to be even stronger and more alive" (Čapek, 1983, p. 362).

The play R.U.R. occupies a wholly specific place in our evaluation of Čapek's work. It is forever ingrained in the world's spiritual culture for first using the word robot (which, however, came from the writer's brother Josef). It is also an important contribution to world science fiction, which took a major change in direction and the form of human ideas about the future a hundred years ago.

This play tends to be interpreted not only as a warning against the discharge of technology turning upon its creators. It also tends to be seen as symbolising the threat of the massification of human civilization, the tyranny of the crowd and also a warning reflection on the Russian Bolshevik Revolution. ${ }^{13}$ We will deliberately set aside these ideological interpretations, in order to emphasise that bioethical aspect. Once again, it is the importance of the category of life ${ }^{14}$ in Capek's overall concept of this play. Although it is anti-utopian in the true sense of the word, ending with the destruction of mankind, Čapek again associated it with the comedy genre. The close of the play bears a message of hope that life similar to human life will continue. Čapek did not want to write a play about robots, but primarily about people, about the lasting value of humanity, which can also achieve miracles - the humanization of those new beings originally created by humans (Čapek, 1968, p. 302).

Also associated with this is the author's remarkable initial concept of artificial beings. In Capek's work, robots are the product of scientific research, not technical development. To be specific, this means that they are not mechanical structures, but are essentially biochemical. Incidentally, Čapek was very unhappy about how other authors usurped his thoughts when they offer the idea of robots as mechanical constructs (Čapek, 1968, p. 304). In the general framework of Čapek's view of the phenomenon of life this means that the author is basing his work on our persistent ignorance of the secrets of the nature and origin of life - which would not be possible in the case of mechanical constructs. And a magical solution (Golem) is also unacceptable for a modern audience. In this way Čapek bows before the mysteries of life, when he writes the following about himself (as an author) and about the scientific basis for his thoughts: "Perhaps as a scientific layman he would be tempted to impute this patient and ingenious scientific task, that one day he makes an artificial living cell in a test tube; but for many reasons, including respect for life, he could not bring myself to treat this mystery so lightly" (Čapek, 1968, p. 304).

Capek's robots did not originate in a complete revelation of the essence of life. They originated from artificially synthesized organic matter, which is not the same as the substances on which terrestrial life is based, but even though, it does behave as though it were alive. “... it

\footnotetext{
${ }^{13}$ In his review, J. Fischer pointed out that R.U.R. it is not a response to the current political situation, but rather deals with social rebellion in a general sense (Fischer, 1921, p. 74).

${ }^{14}$ The biologist B. Němec therefore writes about Čapek’s vitalist tendency (Němec, 1921, p. 42).
} 
is something like a different alternative to life, a material substrate in which life could develop, if another way had not been taken from the beginning... a new substrate was created, which could become a vehicle for life - but life which remains an inexorable and incomprehensible secret" (Čapek, 1968, p. 304).

Here praise is due for Čapek's inventiveness as an author, which rejected a simple and superficial literary solution (either a machine or a crucial - although unexplained breakthrough in our understanding of the essence of life). This rejection stemmed from the author's desire to warn against the reckless use of incomplete fragments of knowledge. ${ }^{15}$ In this context, it can be noted that R.U.R. does not yet reflect environmental risks. Nevertheless, Čapek's concept implicitly solves a serious ecological problem - the introduction of a synthetic species into natural ecosystems and the evolutionary impacts. The robots do not reproduce.

In 1935 Capek returned to his critical view of the further fate of robots. This time, however, he set that rejected shift towards a mechanical concept of robots within a civilization framework and the value transformations it produced: "However, it proved that the modern world is not interested in his scientific Robots and it replaced them with technical Robots. The world ... believes in machines more than in life; it is more fascinated by technical wonders than by the miracle of life. So the author, who wanted to use his rebellious soul-seeking robots to protest against the mechanical superstition of our time, eventually claims something that no one can deny him: the honour of being defeated" (Čapek, 1968, p. 305).

Ćapek's literally initiatory play may thus be interpreted as a remarkable attempt at a warning that is seriously linked to the problem of the value of life, questions concerning the essence of humanity and responsibility for the consequences and products of scientific advancement. ${ }^{16}$

\section{Conclusion}

To conclude this study we will now focus briefly on another aspect of bioethics that can also be traced in Čapek's work. These are environmental matters and so-called animal ethics. "In fact, his Utopias are an indirect means of defending nature against industrialisation ad absurdum" (Bartůšková, 1990, p. 127).

In his famous texts Zahradníkiov rok [The gardener's year] and Kalendár [Calendar] (a summary edition of Čapek's newspaper columns) we see the author as an avid gardener, who loved the beauty of nature (and was directly involved in helping to protect it). Although Capek was not a fervid environmentalist, we do find this comment on how people behave in the countryside: "Don't we know everything about the mysterious symbiosis of the forest, don't we know how the lives of fungi and the lives of trees are connected? And even if they were not: it is a sin to strip the forest of its gnomic fungal life, and to rob the meadows and the elves of the life of flowers; and people who do not leave a piece of untouched natural poetry behind them wherever they go do not belong in the woods and deserve to be chased by the gamekeeper, with tongues of flame and a knotty stick. Some preaching in school could help here; and mainly - it is, I'd say, a matter of democratic sentiment: to avoid as much as possible denying things outside us the right to life, even if such things are merely forest gnomes" (Čapek, 1983, p. 317). Čapek holds nature in high regard, appreciates its beauty and from it draws relaxation and inspiration for his thoughts, which occasionally extend as far as philosophical and ethical questions. And regarding man's relationship with the world he notes: "We imbued with value

\footnotetext{
${ }^{15}$ In real life this hasty applied optimism can be found in the theory and horrific practice of eugenics (Nazi Germany and other countries).

${ }^{16}$ In this respect this play is an unquestionable source of inspiration not only for sci-fi itself, but also for philosophically and ethically formulated questions. Subsequent development also led to deeper thinking in sci-fi - e.g. in Asimov's formulation of the laws of robotics, in the themes of the determination of humanity and responsibility in B. Aldiss's story Super Toys Last All Summer Long (the basis for Spielberg's film A.I.) or in Egon Bondy's Nepovídka.
} 
the snow and water, the sun and the air and movement; we have made the world more beautiful and more precious. Mastering the forces of nature is a great gain; yet the same great gain lies in the appreciation of natural forces" (Čapek, 1983, p. 253).

Living with animals also became a source of inspiration for Čapek - in his work for children (Dášeňka), as well as that for adults (Měl jsem psa a kočku [I Had a Dog and a Cat]). His affinity with animals is imbued with a loving understanding and a gentle humour, with which he describes the experiences of dog and cat owners and the characteristics of the nature and behaviour of those animals: "There is much truth in the saying that people get a dog so as not to be alone. A dog really does not want to be alone" (Čapek, 1983, p. 127). A dog and man basically belong together: "A dog alone is as serious as a lion, a snake or an office manager; his humour and playfulness only emerge when in company with a person, knowledge of which fact belongs to the natural history of the dog and to the natural history of humour" (Čapek, 1983, p. 147).

This is pleasant reading, very adroitly portraying a situation anyone who has ever owned a pet will be familiar with. Čapek has respect for living things, holds their lives in esteem and is able to write about them very convincingly. This is obviously not theoretical animal ethics, but more of an applied philosophy of practical life. ${ }^{17}$

Čapek is convinced that our animal companions play an important cultivating role in our lives. Through our love for animals, we also become better people. And, what is more, that love is lavishly reciprocated: "However, there is one unwritten dog commandment that says: You will love your master. - Some serious people, such as Otokar Březina, see a dog's devotion as a sign of a low and slave-like nature. I object to this too, as from the term slave-like nature we can hardly imagine something as bursting with life and enthusiastic as the nature of a dog ... More than all animals and people the dog is gifted with a special power of joy and grief" (Čapek, 1983, pp. 133-134). And we should not forget that - Čapek's apocryphal Bratr František [Brother František] (Čapek, 2016, pp. 134-138) is therefore a call to empathise with the suffering of the dog's soul. What a difference this is compared to another text from the same time - Sandor Márai's novel Čutora - pes s charakterem [Čutora - a dog with character] (Marai, 2005) by. The failure to understand the dog's nature and especially the incredible brutality at the end is entirely opposite to Čapek's loving view of the co-existence of man and animal, and even of some of their similarities: "The cat is mysterious as an animal; the dog is naive and simple as a man. The cat is something of an aesthete. The dog is like an ordinary person. Or like a creative person. It has something that turns to someone else, to everyone else; it does not live solely for itself" (Čapek, 1983, p. 213). Although with Čapek this is relaxing reading, it in no way reduces the quality or thoughtfulness of the positive effect it has on whole generations of readers.

In this study we have attempted to present a hitherto unseen perspective on the literary legacy of Karel Čapek. We trust that we have managed to convincingly show that this work is relatively rife with questions that we consider to be legitimate bioethical issues. The themes of human life and health, man's relationship to the environment and animals - these are all (obviously to a varying degree) featured in Čapek's work. The central concept of Čapek's philosophy and his entire literary work is, after all, life. Karel Čapek took up a task for himself - to serve life throughout all his work. And as he writes in his Kritika slov [Critique of words]: "However, I am approached by the spirit of the tempter, who asks: Do you consider life to be something perfect, or imperfect? - Very imperfect. - Do you acknowledge and believe that there is something more perfect and higher than life, something above life, or not? - Yes, I do; I acknowledge and believe this. - So why do you not want to use this reason of yours to serve

\footnotetext{
${ }^{17}$ From our modern-day perspective we might find certain problematic moments in Čapek's texts (e.g. taking rare species of plants from the countryside and replanting them in a garden, or the killing of unwanted puppies). However, this was normal practice for the time.
} 
this perfect and higher calling? - Because I would like to serve life in some way. - And why do you want to serve life in some way? - Because it is very imperfect. - The spirit of the tempter laughed at this and said: This shows you are going round in vicious circles. - Yes, mischievous spirit, but noli tangere circulos meos. Touch not my vicious circles" (Čapek, 1969, p. 117).

\section{References}

BARTU゚ŠKOVÁ, S. (1990): Př́roda v díle Karla Čapka [Nature in the Works of Karel Čapek]. In: L. Vacina (ed.): Karel Čapek. Sborník př́spěvků z Národní konference kstému výroči autorova narozeni. [Karel Čapek: Book of proceedings from the national conference to 100th anniversary of author's birth]. Hradec Králové: State Scientific Library, pp. 124-128.

BRADBROOK, B. R. (1961): The Literary Relationship between G. K. Chesterton and Karel Čapek. In: The Slavonic and East European Review, 39(93), pp. 327-338.

ČAPEK, K. \& ČAPEK, J. (1910): Poznámky o Jánošíkovi [Notes on Jánošík]. In: Přehled 3(9), pp. 73-75.

ČAPEK, K. (1918): Pragmatismus čili Filosofie praktického života [Pragmatism, or The philosophy of the practical Life]. Praha: F. Topič.

ČAPEK, K. (1953): Válka s mloky [War with the newts]. Praha: Československý spisovatel.

ČAPEK, K. (1956): Hry [Plays], ed. M. Halík. Praha: Ceskoslovenský spisovatel.

ČAPEK, K. (1968): R. U. R. In: M. Halík (ed.): Divadelníkem proti své vuili. Recenze, stati, kresby, fotografie [A playwright against his will: Reviews, essays, drawings, photographs]. Praha: Orbis, pp. 296-305.

ČAPEK, K. (1969): V zajetí slov: kritika slov a úslovi [Captivated by words: Critique of words and sayings], ed. M. Halík. Praha: Svoboda.

ČAPEK, K. (1983): Spisy XII. Zahradnikưv rok, Měl jsem psa a kočku, Kalendář [Writings XII. The gardener's year, I had a cat and a dog, Calendar]. Praha: Československý spisovatel.

ČAPEK, K. (1989): Krakatit. Praha: Československý spisovatel.

ČAPEK, K. (2016): Kniha apokryfi [Apocryphal stories]. Praha: Vyšehrad.

DINAN, M. (2017): The Robot Condition: Karel Čapek's R.U.R. and Hannah Arendt on Labor, Technology and Innovation. In: Perspectives on Political Sciences, 46(2), pp. 108-117.

FISCHER, J. (1921): Nová utopie. Sociálně-filosofické poznámky k R.U.R. [New utopia: Socio-philosophical remarks on R.U.R.] In: Jeviště. Divadelní týdenník, 5, pp. 73-75.

GABRIEL, J. (2002): Karel Čapek a pragmatismus [Karel Čapek and pragmatism]. In: J. Šmajs (ed.): Bratislavské přednášky. Brno: Masaryk University, pp. 25-33.

HARKINS, W. E. (1958): Pragmatism and the Czech ,pragmatist Generation”. In: American Contributions to the fourth international Congress of Slavistics, Moscow, September 1958. 'SGravenhage: Mouton \& Co, pp. 106-126.

HARKINS, W. E. (1962): Karel Čapek. New York \& London: Columbia University Press. HARKINS, W. E. (1992): Čapek's Early Work Revisited. In: M. Makin \& J. Toman (eds.): On Karel Čapek: Michigan Slavic colloquium. Ann Arbor: Michigan Slavic Publications, pp. 4350 .

HODROVÁ, D. (1987): Utopie. In: Poetika české meziválečné literatury (Proměny žánrů) [Poetics of Czech interwar literature: Transformations of genres]. Praha: Československý spisovatel, pp. 80-104.

KINYON, K. (2014): The Phenomenology of robots: Confrontation with death in Karel Čapek's R.U.R. In: A. B. Evans (ed.): Vintage visions: Essays on early science fiction. Middletown, CO: Wesleyan University Press, pp. 240-266.

MÁRAI, S. (2005): Čutora - pes s charakterem [Čutora - A dog with character]. Praha: Academia.

NĚMEC, B. (1921): Umělí lidé [Artificial people] In: Česká revue, 1, pp. 40-42. 
POPELOVÁ, J. (1962): Etika. K historické a současné problematice mravní teorie [Ethics: On historical and contemporary problems of moral theory]. Praha: Nakladatelství ČSAV.

VOROVKA, K. (1929): Americká filosofie [American Philosophy]. Praha: Sfinx.

ZOUHAR, J. (1998): Karel Čapek. In: J. Gabriel (ed.): Slovník českých filozofü [Dictionary of Czech philosophers]. Brno: Masaryk University, pp. 79-81.

ZOUHAR, J. (2008): Ke vztahu filozofie a krásné literatury [On the relationship between philosophy and fiction]. In: I. Pospíšil \& J. Zouhar (eds.): Literatura a filozofie (Zdeněk Mathauser) [Literature and philosophy: Zdeněk Mathauser]. Brno: Masaryk University, pp. 191-194.

\section{Selected bibliography ${ }^{18}$ of English translations of the works of K. Čapek}

Krakatit, trans. L. Hyde. London: Geoffrey Bles, 1925.

The gardener's year, trans. M. \& R. Weatherall. London: George Allen \& Unwin, 1931.

War with the newts, trans. M. \& R. Weatherall. London: George Allen \& Unwin, 1937. I Had a Dog and a Cat, trans. M. \& R. Weatherall. London: George Allen \& Unwin, 1940. Apocryphal stories, trans. D. Round. London: George Allen \& Unwin, 1949.

Four plays: R.U.R., The Insect Play, The Makropulos case, The White plague, trans. P. Majer \& C. Porter. London: Methuen, 1999.

\footnotetext{
${ }^{18}$ Not all of Čapek's works used in this text are available in English translation.
} 